\title{
TUGAS AUDIT SISTEM INFORMASI
}

"Macam-Macam Devinisi Audit”

\author{
Santy Karina \\ 175100051 \\ Universitas Mitra Indonesia \\ santykarina.student@umitra.ac.id
}

\begin{abstract}
ABSTRAK
Sekarang sangat lah di perlukan dan di gunakan teknologi informasi karena saat ini setiap perusahaan memerlukan seseorang yang sangat menguasai teknologi informasi, dan semakin tahun semakin canggih maka kita harus terus belajar dan menguasai.
\end{abstract}

\section{- DEFINISI AUDIT MENURUT AHLI}

\section{Menurut Alvin A.Arens dan James K.Loebbecke}

Auditing is the accumulation and evoluation of evidence abou information to determine and report on the degree of correspondece between the information and estabilshed criteria. Auditing should be done by a competent independent person.

\section{Menurut Mulyadi}

Suatu proses sistematik untuk memperoleh dan mengevaluasi secara obyektif mengenai pernyataan-pernyataan tentang kegiatan dan kejadian ekonomi, dengan tujuan untuk menetapkan tingkat kesesuaian antara pernyataan-pernyataan tersebut. Dengan kriteria yang di terapkan serta penyampaian hasil-hasilnya kepada pemakai yang berkepentingan.

\section{Menurut Sanyoto}

Audit berasal dari bahasa latin "audire" yang memiliki arti mendengar atau to hear, yaitu pada zaman dahulu apabila seorang pemilik organisasi usaha merasa ada suatu kesalahan atau penyalahgunaan, maka ia akan mendengarkan kesaksian orang testentu. 


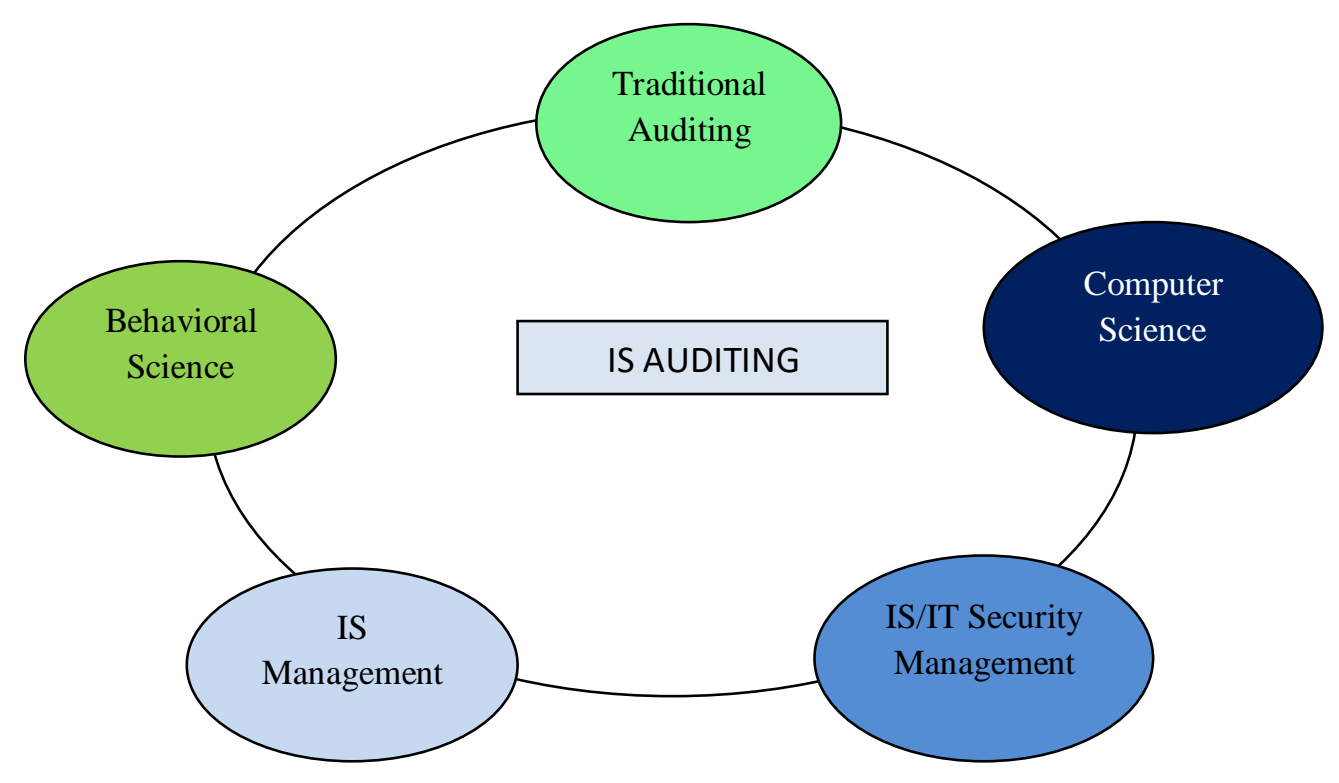

\section{FAKTOR-FAKTOR BERIKU YANG PERLU DI PERHATIKAN}

- Kriteria (standar) yang dapat digunakan sebagai panduan untuk mengevaluasi

- Periode waktu dan ruang lingkup yang diaudit harus jelas

- Bahkan bukti dalam jumlah dan kualitas yang cukup

\section{- TIPE-TIPE AUDIT}

1. Audit laporan keuangan (Financial Statement Audit)

Bertujuan Untuk Memeriksa Kesesuaian Dengan Kriteria-Kriteria Yang Telah Diterapkan.

2. Audit Kepatuhan (Compilance Audit)

Bertujuan Untuk Menentukan Apakah Yang Diperiksa Sesuai Dengan Kondisi,Peraturan Dan Undang-Undang Tertentu. 
3. Audit Operasional (Operational Audit)

Merupakan Penelahan Secara Sistematik Aktivitas Operasi Dalam Hubungan Dengan Tujuan Tertentu.

- JENIS AUDIT

- Eksternal

- Internal

\section{- DISKUSI}

Dari hasil diskusi di atas terrnyata audit sangatla berguna dan sangat penting untuk mengevaluasi kegiatan pada organisasi dan maupun usaha.

\section{- REFRENSI}

- Ruangkampus.id Section 01 Definisi Audit.

-Ruangkampus.id Section 02 Tipe Audit 